\title{
The Nature Park movement in Austria - from recreational areas to(wards) model regions for sustainable development
}

\author{
Valerie Braun \\ Keywords: Nature Parks, Austria, development of objetives
}

\section{Abstract}

In Austria, Nature Parks (NaP) are the oldest large protected areas. The first NaPs were created both as recreational areas for the urban population of Vienna, and to encourage economic growth in rural cultural landscapes. Twenty years after the first characteristic landscapes were designated to protect their uniqueness without preventing their economic development, working groups were established to concentrate on the further development and establishment of NaPs. With the foundation of the Association of Austrian NaPs, an umbrella organization, a common strategy for all Austrian NaPs was developed and implemented. Today, the strategy of NaPs is to simultaneously protect natural and cultural landscapes and to become model regions for sustainable development. This article highlights the development of NaPs in Austria from recreational parks for the urban population to model regions for sustainable development.

\section{Foundation of Nature Parks}

The idea of the establisment of Nature Parks $(\mathrm{NaPs})$ in Austria ran almost parallel to the emergence of the idea in Germany. In 1956, Dr. Alfred Toepfer, chairman of the NaP Association, had proposed a programme of twenty-five $\mathrm{NaPs}$ in Germany at the association's annual meeting (Liesen et al 2008) and in 1959 an Austrian geographer, building on Toepfer's idea, proposed twelve NaPs in Austria (Strzygowskin 1959). Only a few years later, in 1962, the first $\mathrm{NaP}$ was founded leading to a series of nature park foundations until 2012 (see Table 1):

- In the 1960s, first establishment of NaPs in Lower Austria.

- In the 1970s, nine NaPs were designated in Lower Austria which were regarded as cultivated nature for recreation purposes (Schweiger 1980).

- In the 1980s, large areas with distinctive landscapes were designated in Styria.

- In the 1990s, the first NaP in Upper Austria was founded to maintain the small-scale structure of the area's particular cultural landscape (Bauernfeind 1996). Two cross-border NaPs were also established with Hungary, in Burgenland.

- Between 2000 and 2012, 19 NaPs were created, amounting to almost 318000 ha (Verband der

Table 1 - Foundation of Nature Parks in Austria (Verband der Naturparke Österreichs 2019).

\begin{tabular}{|l|r|r|l|}
\hline Period & Number & Size [ha] & Federal state \\
\hline $1960-1969$ & 3 & 2817 & Lower Austria \\
\hline $1970-1979$ & 10 & 50900 & Lower Austria, Burgenland \\
\hline $1980-1989$ & 10 & 77278 & Lower Austria, Styria \\
\hline $1990-1999$ & 4 & 82889 & $\begin{array}{l}\text { Styria, Burgenland, Upper } \\
\text { Austria }\end{array}$ \\
\hline $2000-2012$ & 19 & 317943 & $\begin{array}{l}\text { Lower Austria, Styria, } \\
\text { Burgenland, Tyrol, Salzburg, } \\
\text { Carinthia }\end{array}$ \\
\hline Total & 46 & 531827 & 6\% of the total area of Austria \\
\hline
\end{tabular}

Naturparke Österreichs 2019a), the last one being NaP Attersee-Traunsee; yet the idea for a NaP in this area was already being considered in 1967 (Fossel \& Probst 1988). No further NaP has been designated since 2012.

Today, NaPs cover almost $6 \%$ of the total area of Austria. They differ in size and cover the most diverse cultural landscape types. The smallest $\mathrm{NaP}$ is $\mathrm{NaP}$ Falkenstein-Schwarzau/Gebirge in Lower Austria, with 17 ha; the largest is $\mathrm{NaP}$ Karwendel in Tyrol, with 72741 ha.

\section{The development of the objectives and functions through time}

For Germany, where the focus from the beginning was on conservation, Weber \& Weber (2015) describe five phases in the development of the objectives and functions of NaPs through time. The four phases that can be identified in Austria, where the original purpose was to create recreational areas for the urban population, differ slightly from these. Yet the main long-term aim in both countries is for $\mathrm{NaPs}$ to become model regions for sustainable development (Table 2).

\section{Phase 1}

The increasing motorization of the population in the 1950s and 1960s and the reduction of the working week to forty hours both increased recreational time and made it possible to travel further. In order to offer the urban population of Vienna recreational possibilities in suitable cultural, touristic and natural areas (Machura 1965a) the first NaP in Austria, the Sparbach $\mathrm{NaP}$, was founded in 1962 in Lower Austria, near Vienna, in the Vienna Woods.

In 1964, Blockheide Gmünd-Eibenstein $\mathrm{NaP}$ was established to protect the area's free-standing granite blocks from economic use and to guarantee the population an economic upturn through tourism (Machura 
Table 2 - Overview of the objectives of NaPs in Austria. Based on Weber \& Weber (2015) who describe 5 phases in the development of the objectives and functions of NaPs through time in Germany.

\begin{tabular}{|l|l|}
\hline \multirow{3}{*}{ Phase 1} & Objectives \\
\cline { 2 - 3 } & Creation of recreational areas for the urban population of Vienna \\
\cline { 2 - 3 } & Protection of threatened landscape elements \& economic upturn through tourism \\
\hline \multirow{3}{*}{ Phase 2} & Preservation of landscapes for recreation threatened by second homes \\
\cline { 2 - 3 } & Creation of a landscape conservation plan \\
\cline { 2 - 3 } & Establishment of educational and information services \\
\cline { 2 - 3 } & Development of the region towards sustainable tourism \\
\cline { 2 - 3 } & Improvement of the ecological and economic foundations \\
\hline Phase 3 & Establishment of the Association of Austrian NaPs \\
\cline { 2 - 3 } & Publication of a strategy paper defining four objectives: protection, recreation, education and regional development \\
\cline { 2 - 3 } & Implementing NaPs as model regions for sustainable development \\
\hline Phase 4 & New designations of NaPs in six federal states of Austria \\
\hline
\end{tabular}

1965b). The increasing prosperity and the growing desire for recreation of the Viennese population led to a significant increase in second homes in Lower Austria (Machura 1962; Schweiger 1980); "In order to preserve the last natural areas threatened by disorderly settlement development as recreational areas," the Hohe Wand NaP was founded in 1969 (Machura 1965b). NaPs were thus seen as selected landscapes being particularly suitable as recreation areas and for this purpose carried out protection, as well as maintenance and design measures (Schweiger 1980).

\section{Phase 2}

In 1976, the new Styrian Nature Conservation Act stipulated that the provincial government could award the designation Nature Park to a generally accessible landscape area that already included a protected area (NatSchG Stmk 1976, \8). In Styria, only one NaP per characteristic landscape should be established (Fossel 1983). A landscape conservation plan drawn up in accordance with the Nature Conservation Act and in cooperation with representatives of agriculture, forestry, nature conservation and tourism aimed to set out the necessary measures, including establishing educational and information services and improving the ecological and economic foundations, to create $\mathrm{NaPs}$ and to steer the region's development towards sustainable tourism (NatSchG Stmk 1976, §8; Fossel 1983). In the same year three individual communities which have since merged to Sölktäler have taken up the idea and negotiated with the Styrian provincial government about the establishment of a NaP to improve the local economic structure and make tourism more attractive (Fossel 1976). Six years later in 1982, the first Styrian NaP, Sölktäler, was founded. In the same year, Grebenzen Furtnerteich and Pöllauer Tal NaPs (both in Styria) were also established.

\section{Phase 3}

In 1994, a survey of Austria's NaPs was carried out, resulting in a strengthening of the cooperation between the Austrian NaPs. This was reflected in defining a joint presentation of the objectives of the $\mathrm{NaPs}$ and distinguishing themselves clearly from the other existing protection categories (Verband der Naturparke Österreichs 2015). One year later, in 1995, the founding meeting of the Association of Austrian $\mathrm{NaPs}$ took place. The aims of the Association are the qualitative development of $\mathrm{NaPs}$ and the implementation of joint marketing projects.

\section{Phase 4}

The number of new designations after 2000 suggests that the $\mathrm{NaP}$ label became increasingly important as a protected area category for regions where sustainable tourism could coexist with the cultural landscape. The increase in the number of $\mathrm{NaPs}$ could also be due to the Year of the NaPs in 1999, since one of its aims was to increase the parks' visibility through a variety of events (see for example Österreichischer Naturschutzbund 1999).

\section{Organizational and financial structure}

Nature protection in Austria is the responsibility of the nine federal states, leading to different modes and dates of implementation. Common to all $\mathrm{NaPs}$ is that they must include protected areas and that only with the consent of all affected communities the nature conservation title Nature Park is awarded. The Austrian $\mathrm{NaPs}$ are either administered by non-profit associations that carry out the tasks on their behalf, or work with their own management teams under the umbrella of a regional development organization (Verband der Naturparke Österreichs 2017). In addition, NaPs benefit from the voluntary cooperation of individuals and associations, and from local initiatives.

The financial structures of Austrian $\mathrm{NaPs}$ are very heterogeneous, both in terms of the amount of funds available and the sources of finance. Funding is provided by the provinces, the European Agricultural Fund for Rural Development, and contributions from local authorities. $\mathrm{NaP}$ activities, membership fees, donations, sponsoring and project support are further sources of funds (Verband der Naturparke Österreichs 2017). Yet the need for parity of funding across 


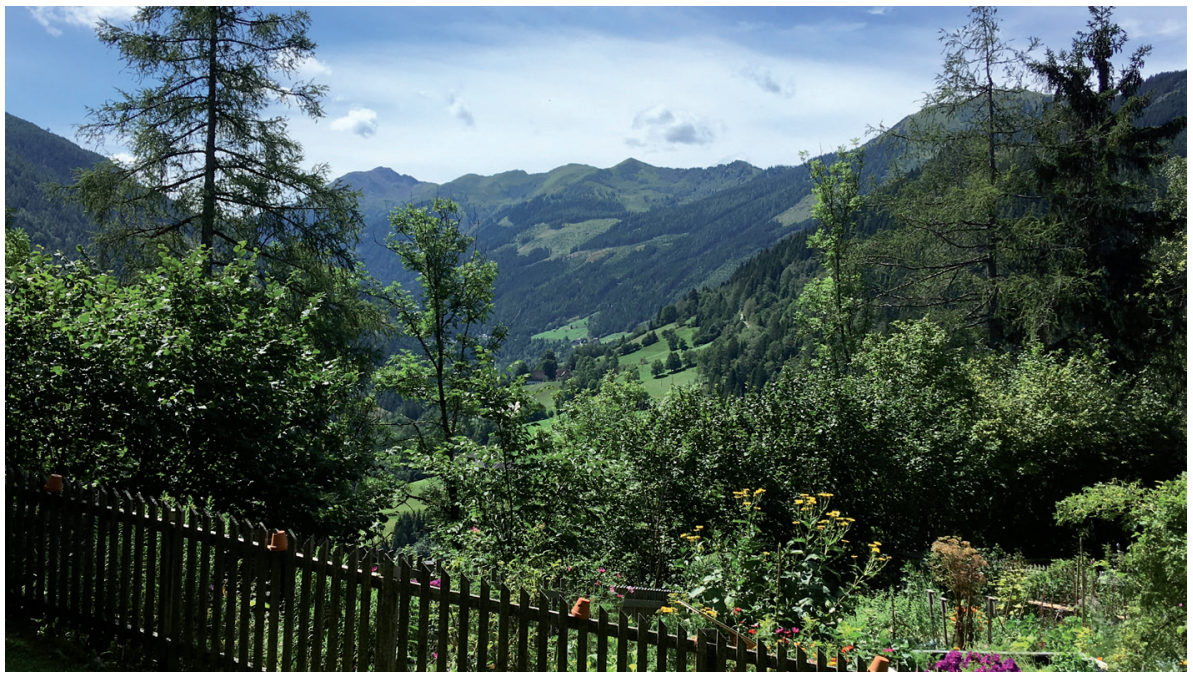

Figure 1 - Nature Park Sölktäler in Styria. (C) Valerie Braun

all types of protected area is often articulated (CIPRA 2002; Ketterer \& Siegrist 2009), because only with the appropriate financial support can $\mathrm{NaPs}$ become model regions for sustainable development (Gamper et al. 2007). The same is true for Germany, where NaPs are less well funded and have fewer human resources than other types of protected areas (Weber \& Weber 2015), even though the tasks of NaPs are manifold (Lisen \& Weber 2018).

\section{Regional governance}

Regional governance is the transdisciplinary cooperation of actors from politics, administration, business and civil society. This cooperation began with the establishment of the first NaPs in Austria, when various working groups were founded before the creation of the Association of Austrian $\mathrm{NaP}$ in order to coordinate different interest groups and activities with other NaPs (see Table 3). Until today NaPs depend on cooperation with other actors in order to achieve their goals and to carry out a variety of tasks. They combine various functions, such as nature conservation, tourism, environmental education, regional development, and managing renewable energies, agriculture and forestry (Mehnen et al. 2018). Yet the quality and intensity of regional cooperation is greatly influenced by the natural environment, location, history and previous experience in regional development (Pütz \& Job 2016).

\section{The four objectives and their development from the first establishement to the present}

\section{The four objectives of the Austrian NaPs}

In order to facilitate the future position of the Austrian NaPs within the framework of nature conservation legislation and to distinguish them from the various categories of protected areas a coordination group consisting of representatives of the NaPs and the nature conservation departments of the provinces

Table 3 - Working groups in Austria founded before the creation of the Association of Austrian Naturpe Parks (NaPs) in order to facilitate the coordination of different interest groups and activities.

\begin{tabular}{|c|c|c|c|c|}
\hline Working group & Foundation & Participants & Objectives & Source \\
\hline $\begin{array}{l}\text { NaP Working Group } \\
\text { (Arbeitsgemeinschaft } \\
\text { Naturparke) }\end{array}$ & 1968 & $\begin{array}{l}\text { Representatives from economic organiza- } \\
\text { tions, municipalities, agricultural and for- } \\
\text { estry enterprises, hunting, tourism, spatial } \\
\text { planning, car clubs, alpine associations and } \\
\text { nature conservation }\end{array}$ & $\begin{array}{l}\text { Preparation of guidelines for the creation } \\
\text { of NaPs; public relations and recreation } \\
\text { in rural areas; cooperation with govern- } \\
\text { ment agencies and public corporations; } \\
\text { landscape conservation; financial support } \\
\text { of concrete projects }\end{array}$ & $\begin{array}{l}\text { Anonymous } \\
1970\end{array}$ \\
\hline $\begin{array}{l}\text { Working group } \\
\text { for NaPs } \\
\text { (Arbeitsgemeinschaft } \\
\text { für Naturparke) }\end{array}$ & 1981 & $\begin{array}{l}\text { NaPs Pöllau, Sölktäler and Grebenzen, } \\
\text { Nature Conservation Department, Tourism } \\
\text { Department of the federal state of Styria, Agri- } \\
\text { cultural Authority, representatives of Mountain } \\
\text { and Nature Watch, National Chamber for } \\
\text { Agriculture and Forestry }\end{array}$ & $\begin{array}{l}\text { Coordination of common goals; exchange } \\
\text { of experience; elaboration of common } \\
\text { documents for information and education; } \\
\text { mediation of knowledge and experiences of } \\
\text { nature; recreation close to nature; increase } \\
\text { income from natural capital (development } \\
\text { without destruction) }\end{array}$ & $\begin{array}{l}\text { Anonymous } \\
1981\end{array}$ \\
\hline $\begin{array}{l}\text { Austrian Working } \\
\text { Group for NaPs } \\
\text { (Österreichischen } \\
\text { Arbeitsgemeinschaft } \\
\text { für Naturparke) }\end{array}$ & 1984 & $\begin{array}{l}\text { Representatives of municipalities and } \\
\text { tourism, naturalists, folklore specialists, his- } \\
\text { torians, spatial planners, artists, representa- } \\
\text { tives of agriculture and forestry, doctors }\end{array}$ & Exchange of experience and information & $\begin{array}{l}\text { Anonymous } \\
1984 \text {; Fos- } \\
\text { sel } 1989\end{array}$ \\
\hline
\end{tabular}


Table 4 - The four objectives of Austrian Naturpe Parks (NaPs) according to the Austrian NaP strategy paper (Verband der Naturparke Österreichs 2015).

\begin{tabular}{|l|l|}
\hline Protection & $\begin{array}{l}\text { The aim is to safeguard the diversity and beauty of the natural environment through sustainable use and to } \\
\text { preserve the centuries-old cultural landscape. }\end{array}$ \\
\hline Recreation & $\begin{array}{l}\text { The aim is to offer attractive, well-kept recreational facilities in accordance with the protected area and the char- } \\
\text { acter of the landscape. }\end{array}$ \\
\hline Education & $\begin{array}{l}\text { The aim is to use interactive ways of understanding and experiencing nature to make nature, culture and their } \\
\text { interrelationships tangible in the context of education for sustainable development. }\end{array}$ \\
\hline Regional development & $\begin{array}{l}\text { The aim is to use the NaP to stimulate regional development in order to increase regional added value and } \\
\text { safeguard the quality of life. }\end{array}$ \\
\hline
\end{tabular}

concerned drew up a strategy paper that was unanimously approved by the board of the Austrian Association of $\mathrm{NaPs}$ (Verband der Naturparke Österreichs 2015; Verband der Naturparke Österreichs 2019b). This paper defined the four objectives as protection, recreation, education and regional development. The objectives are given equal importance, and if $\mathrm{NaPs}$ succeed in developing all these functions at the same time, they can establish themselves as model regions for sustainable development. In Tyrol, a further objective, research, was added (Verband der Naturparke Österreichs 2015).

Nature conservation and recreation in $\mathrm{NaPs}$, from 1960 to the present

In Austria, nature conservation and recreation are strongly interconnected. The first $\mathrm{NaPs}$ in Austria were established in areas which would have lost their cultural and natural character through urban sprawl or economic use. By protecting these areas for tourism, the initiators assumed that they would be preserving habitats for fauna and flora at the same time. Yet critics claimed that drawing large numbers of visitors to attractive destinations endangered sensitive habitats for flora and fauna (Fischer 1982). One Viennese spatial planner characterized $\mathrm{NaPs}$ as follows: " $\mathrm{NaP} / s]$ are primarily dedicated to nature-oriented leisure activities for people. They are therefore not protected areas (reserves) in the sense of traditional nature conservation, although they can include full and partial nature reserves as well as natural monuments" (Bernt 1972 in Schweiger 1980). This lack of nature conservation per se led critics to demand that in areas that are "characterized by a high degree of originality or where the rarest animal and plant communities still occur, the idea of $\mathrm{NaP}$ must be exercised with extreme restraint. The fact is that, as practice has shown, areas with a distinct reserve character cannot be reconciled with mass tourism" (Schweiger 1980). Yet people working with and for $\mathrm{NaPs}$ claimed that the simultaneous economic and ecological development of the $\mathrm{NaP}$ regions should be possible (Schweiger 1980; Fossel 1983). In 2002, the Alpine NaP technical committee drew up criteria for a nature conservation profile for $\mathrm{NaPs}$, as tourism had increased and the idea of nature conservation moved to the background (CIPRA 2002). The committee presented guidelines stating that $\mathrm{NaPs}$ should represent characteristic, cultural landscapes that are easily recognizable by their characteristics, and their landscape dynamics should be easy to communicate to visitors. In 2013, the Ty- rolian NaPs published recommendations for guiding visitors in order to safeguard the aims of the $\mathrm{NaPs}$ and to maintain nature as the main player within the parks (Arbeitsgemeinschaft Tiroler Naturparke 2013).

Although the protected area category of $\mathrm{NaP}$ is still recognized more as a tourism label than as an indication of the quality of the area's nature conservation, $\mathrm{NaPs}$ also contribute to numerous EU objectives and strategies, such as the EU Biodiversity Strategy (see also Verband der Naturparke Österreich 2014a, 2017b), the Natura 2000 Network, the Green Infrastructure, the EU Rural Development Strategy and the Europe 2020 Strategy. They also help to implement the Council of Europe's Landscape Convention and the Alpine Convention. Furthermore, NaPs support global agreements such as the Convention on Biological Diversity or the 17 Goals for Sustainable Development of the United Nations (Verband Deutscher Naturparke e.V. 2017).

\section{Education in NaPs, from 1960 to the present}

An important aspect of the $\mathrm{NaP}$ concept is environmental education. After the establishment of the first $\mathrm{NaP}$, the idea soon emerged of bringing people closer to nature and "to awaken sensitivity and love for forest, fauna and flora and water, which would accomplish an educational task" (Machura 1965a). NaPs should lead inhabitants of urban and industrial areas back to nature (Schweiger 1980). Their mere presence in nature should be sufficient for them to gain a better understanding of the natural environment. This attitude changed with the establishment of $\mathrm{NaPs}$ in Styria. They included nature trails, nature guides were published, and short descriptions were attached to places of natural and cultural importance. Today, there are many initiatives and projects which have at their centre the transfer of knowledge and the creation of awareness about the sustainable development of a region and its natural and cultural diversity (see Verband Naturparke Österreich 2014b).

Regional development in NaPs, from 1960 to the present

"NaP planning must fit into a larger economic regional (tourism) concept with concrete maintenance and structural measures, i.e. a NaP must fit into all economic sectors (including agriculture and forestry) - it cannot be realized in isolation from other economic interests." (Fossel 1983) 
As early as 1983, Styria discussed sustainable individual tourism and economic regional concepts for $\mathrm{NaPs}$ (Fossel 1983), with direct marketing of agricultural products and ecological agricultural production. In 1989, two concepts were presented which already contained the idea of sustainable regional development: development without destruction describes $\mathrm{NaPs}$ as areas in which economic development is possible; protecting and utilizing contributes to the preservation of the natural environment as the basis for life and business, thereby increasing the nature capital by means of sensitive management (Fossel 1989). Following the Brundtland Report in 1987 and the Rio Conference in 1992, the course was set for global sustainable development. National and international efforts towards sustainable development were included in the strategy paper of the Association of Austrian NaPs. In 1999, the Association of Austrian NaPs, together with the environmental umbrella organization (Umweltdachverband), proclaimed the Year of NaPs to establish NaPs as model regions for sustainable regional development and to implement Agenda 21 (Maier 1999).

The strength of $\mathrm{NaPs}$ lies in the high quality and value of the natural and scenic characteristics on which their existence is based (Ketterer \& Siegrist 2009). The local population and political will are important if a region is to become a model for sustainable development (Gamper et al. 2007). Such a view of a $\mathrm{NaP}$ can be triggered by implementing such things as educational functions, nature conservation measures or tourist and gastronomic offers, and by generating positive regional economic effects (Böhm 2004). Some NaPs are situated in rural areas (which are often very remote), which may be a weakness, e. g. due to the lack of high-quality accommodation for visitors (Ketterer \& Siegrist 2009). $\mathrm{NaPs}$ can be a driver for regional development in rural areas (Bätzing 2008) yet NaPs do not always fully imply the existence of regional concepts, corresponding measures or future-oriented development strategies (Weber 2012; Heintel \& Weixlbaumer 2004).

\section{Conclusion and Outlook}

$\mathrm{NaPs}$ represent the oldest large protected areas in Austria, are highly appreciated for their touristic values and cultural landscapes, and are considered model regions for regional development. NaPs have benefited greatly from mutual cooperation and cooperation with a wide range of stakeholders. The balancing act of achieving both economic goals in the region and land protection is a big challenge, yet solutions achieved could subsequently be adapted by adjacent regions. Future fields of actions are e. g. the emigration of young people and the simultaneous decrease of cultivated land; climate change and the need to find adaptation and mitigation solutions; overcrowding through tourism in certain areas; the need to fulfil conservation objectives; the protection and communication of ecosystem services. In all of these fields holistic answers must be found for simultaneous protection and use in a global context.

\section{References}

Anonymous 1970. Arbeitsgemeinschaft Naturparke - ein Gremium zur Koordinierung und Unterstützung. Natur und Land 5-6: 151-154. [In German]

Anonymous 1981. Arbeitsgemeinschaft für Naturparke gegründet. Steirischer Naturschutzbrief 21(3): 2324. [In German]

Anonymous 1984. Resolution, eingebracht bei der Generalversammlung des ÖNB am 12.10.1984 in St. Pölten. Naturschutz in der Steiermark - Steirischer Naturschutzbrief 124: 10-11. [In German]

Arbeitsgemeinschaft Tiroler Naturparke 2013. Empfehlungen der Tiroler Naturparke zum Besuchermanagement. [In German]

Bätzing, W. 2008. Der Naturpark als zentraler Motor für Regionalentwicklung - hoffnungslose Überforderung oder sinnvolles Ziel? Mitteilungen der Fränkischen Geographischen Gesellschaft 55: 1-14. [In German] Bauernfeind, J. 1996. Der Naturpark Rechberg ist der erste Naturpark in Oberösterreich. Informativ 4: 14.

Böhm, T. 2004. Regionalwirtschaftliche Auswirkungen durch neue Angebote in den burgenländischen Naturparken. Ländlicher Raum 3: 1-12. [In German]

CIPRA 2002. „Alpine Naturparke" - Broschüre des Fachausschusses. [In German]

Fischer, K. 1982. Landschaftsrahmenplanung Höllengebirge-Hongar. Unveröffentlichtes Gutachten im Auftrag des Amtes der Oberösterreichischen Landesregierung. [In German]

Fossel, C. 1976. Sökltäler - erster steirischer Naturpark. Steirischer Naturschutabrief 16: 17-18. [In German]

Fossel, C. 1983. Natur- und Nationalparke. Was bedeutet das? Naturschutz in der Steiermark - Steirischer Naturschutzbrief 117: 3-6. [In German]

Fossel, C. (1989). Naturparke - Quellen der Gesundheit und Stätten der Bildung. Natur und Land 75 (5-6): 173-177. [In German]

Fossel, C. \&. A. Probst 1988. Chronik der Landesgruppe Steiermark des Österreichischen Naturschutzbundes 139: 14-43. [In German]

Gamper, C., M. Heintel, M. Leitner \& N. Weixlbaumer 2007. NaP s and regional development in austria: a case study of the $\mathrm{NaP}$ Ötscher-Tormäuer. In: Mose, I., Protected areas and regional development in Europe: 75-98.

Heintel, M. \& N. Weixlbaumer 2008. Gebietsschutz und Regionalmanagement. Erfahrungen und Empfehlungen anhand des Naturparks Ötscher-Tormäuer. In: Weixlbaumer, N. \& H. Wohlschlägl, Forschungsberichte Geographie Wien: 149-174. [In German]

Ketterer, L. \&. D. Siegrist 2009. Touristische Potenziale der Österreichischen Naturparke. [In German]

Liesen, J., U. Köster \& M. Porzelt 2008. 50 Jahre Naturparke in Deutschland. Naturschutz und Landschaftsplanung 40(1): 26-32. [In German] 
Liesen, J. \& F. Weber 2018. Regionalentwicklung im Spannungsfeld von Naturpark Saar-Hunsrück und Nationalpark Hunsrück-Hochwald. In: Weber, F., F. Weber \& C. Jenal, Wobin des Weges? Regionalentwicklung in Großschutzgebieten: 122-150. [In German]

Machura, L. 1962. Über den Naturpark von Sparbach. Natur und Land 6: 126-129. [In German]

Machura, L. 1965a. Grundsätzliches über Naturparks. Natur und Land 4: 78-81. [In German]

Machura, L. 1965b. Naturparke in Österreich. Natur und Land 2: 25-29. [In German]

Maier, F. 1999. Erwachen aus dem „Dornröschenschlaf" - Das Jahr der Naturparke 1999. Umwelt und Bildung 1: 30-32. [In German]

Mehnen, N., S. Kabelitz \& J. Liesen 2018. Akteure und Akteurskonstellationen in Naturparken: Wer agiert und kooperiert? In: Weber, F., F. Weber \& C. Jenal, Wohin des Weges? Regionalentwicklung in Großschutrgebieten: 86-121. [In German]

NatSchG Stmk (Steiermärkisches Naturschutzgesetz) 1976. \$8 Naturparke. [In German]

Netzwerk Schweizer Pärke 2019. Panorama Schweizer Pärke 2019. [In German]

Österreichischer Naturschutzbund 1999. Jahr der Naturparke 1999. Natur und Landschaftschutz in der Steiermark 183 (3/99). [In German]

Pütz, M. \& H. Job 2016. Governance und Regionalentwicklung in Großschutzgebieten der Schweiz und Österreichs. Raumforschung und Raumordnung 74(6): 569-583. [In German]

Schweiger, H. 1980. Naturparks - moderne Erholungsräume? Wissenschaftliche Mitteilungen Niederösterreichisches Landesmuseum 1: 63-104. [In German]

Strzygowsk, W. 1959. Europa braucht Naturparke!

UNEP \& UNWTO 2005. Making Tourism More Sustainable - A Guide for Policy Makers.

Verband Deutscher Naturparke e. V. 2017. Landschaften voller Leben. Europas Natur-, Regional- und Landschaftsparke - Modellregionen für die nachbaltige Entwicklung ländlicher Räume. [In German]
Verband der Naturparke Österreichs 2014a. Naturparke und Biodiversität. Grundlagen und Beiträge zum Schutz. und Erhalt der biologischen Vielfalt in den Österreichischen Naturparken. [In German]

Verband der Naturparke Österreichs 2014b. Bildung für nachhaltige Entwicklung in Naturparken.

Verband der Naturparke Österreichs 2015. 20 Jabre Verband der Naturparke Österreichs 1995 bis 2015.

Verband der Naturparke Österreichs 2017a. Österreich Naturparke. In: Verband Deutscher Naturparke e. V., Landschaften voller Leben. Europas Natur-, Regionalund Landschaftsparke -Modellregionen für die nachbaltige Entwicklung ländlicher Räume: 64-67. [In German]

Verband der Naturparke Österreichs 2017b. Österreichische Naturparke Erfahrungen aus der Biodiversitätspraxis in Naturparken. [In German]

Verband der Naturparke Österreichs 2019a. Landschaften voller Leben. Available at: https://www. naturparke.at/naturparke/ [In German]

Verband der Naturparke Österreichs 2019b. Strategie der Naturparke. Available at: https://www. naturparke.at/vnoe/ueber-naturparke/strategie/ [In German]

Weber, F. 2012. Naturparke als Manager einer nachbaltigen Regionalentwicklung: Probleme, Potenziale und Lösungsansätze. [In German]

Weber, F. \&. F Weber 2015. Naturparke und die Aufgabe der nachhaltigen Regionalentwicklung - Jenseits von Wanderwegemarkierern und Parkbankaufstellern. Naturschutz, und Landschaftsplanung 47 (5): 149_ 156. [In German]

Weisen, A. 2009. The park creation boom in Switzerland. eco.mont - Journal on protected mountain research and management 1(2): 67-68. [In German]

\section{Author}

\section{Valerie Braun}

has a $\mathrm{PhD}$ in eco-physiology of alpine plants and is now co-editor of eco.mont. 